\title{
A FESTIVAL AS A PEDAGOGICAL TOOL TO PROMOTE INCLUSION IN THE COMMUNITY AND IN SCHOOLS
}

\author{
Katja Jeznik, Klara Skubic Ermenc, Jasna Mažgon \\ University of Ljubljana, Ljubljana, Slovenia \\ E-mail: katja.jeznik@ff.uni-lj.si, klara.skubic-ermenc@ff.uni-lj.si, \\ jasna.mazgon@ff.uni-lj.si
}

\begin{abstract}
The focus of education policies on greater equity and accessibility of education for all exposes an important difference between narrow and broad definitions of the concept of inclusion. The narrow definition is tied above all to the school context, where responsibility for the realisation of inclusion lies with pedagogical workers. The broad definition refers to an understanding of inclusion as the embracing of diversity as a positive value for the community, regardless of the institutional context in which we endeavour to achieve inclusion. The research discussed the inclusive educational practice of a special educational institution catering for individuals with intellectual disabilities. Using a sample of 139 participants at the international inclusive festival Play With Me, the attitudes towards inclusion and towards persons with special needs (a Likert scale was created) were researched. The results indicate that respondents generally had positive attitudes towards inclusion; there were differences between them, depending on the roles they undertook at the festival (mentors of students taking part in the festival and volunteers running various festival activities), the institutions they came from (special or mainstream educational institutions, associations, NGOs), and whether or not they had experience of individuals with special educational needs (SEN), either in their work or in their studies. Although a broad understanding of inclusive culture is present in the statements of respondents, it appears that both general and special teachers (in the role of mentors) still incline slightly more towards a narrow understanding of inclusion than volunteers do, which raises questions about pedagogical workers' conception of education.
\end{abstract}

Keywords: inclusion understanding, intellectual disabilities, positive attitudes, special educational institution.

\section{Introduction}

The article focuses on the attitudes of those taking part in the inclusively oriented festival Play With $\mathrm{Me}$, which the special educational institution Special Education Centre Janez Levec Ljubljana (Center Janeza Levca Ljubljana) has organised in Slovenia for the past decade in conjunction with the Society for the Culture of Inclusion (Društvo za kulturo inkluzije). The former is a school that caters in the first place for children with intellectual disabilities. The festival aims to promote inclusion and strengthen inclusive culture in the community, ${ }^{1}$ as defined by Booth and Ainscow (2002) in their indicators of inclusion, via relaxed forms of social activity and spontaneous interaction. In the foreground is the desire to shape a secure, accepting and stimulating environment in which all are equally valued. The understanding of inclusivity demonstrated by the festival activities is a broad one, since it goes beyond the educational aspect of inclusion and emphasises the social aspect. This means that inclusion is understood as a value orientation where the acceptance of difference as a positive value of the modern community is in the foreground (Arduin, 2015; Biesta, 2013; Lesar, 2009, 2017; Reindal, 2016; The

1 Taken from the festival website: http://www.igrajsezmano.eu/ProjektIgrajbrsezmano.aspx. 
Katja JEZNIK, Klara SKUBIC ERMENC, Jasna MAŽGON. A festival as a pedagogical tool to promote inclusion in the community and in schools

PROBLEMS

OF EDUCATION

IN THE $21^{\text {st }}$ CENTURY Vol. 76, No. 2, 2018

Salamanca Statement, 1994; Warnock, 2010). The theoretical part of the article discusses the concept of inclusion, including the obstacles that prevent its full implementation in education, and links it to the Slovenian context. The research part of the article presents some results of a research in which attitudes towards inclusion of those taking part in the festival were measured.

\section{From a Narrow Understanding of Inclusion to a Broad One}

Despite the fact that the concept of inclusion was introduced back in the mid-1990s by the Salamanca Statement (1994), more than two decades later there are still no clear-cut theoretical definitions of what inclusion means. In fact, pluralisation of definitions can be traced; some of them are focused above all on the definition of indicators and elements of inclusion (Booth \& Ainscow, 2002; Florian, 2014; Mitchell, 2015), while in recent years some researchers (Arduin, 2015; Haug, 2017) have been focusing on the classification of the stages of development of the concept of inclusion.

Haug (2017) identifies three stages of development of the concept of inclusion. He places its beginnings in the 1960s, when some countries began to include students with special needs (SEN students) in mainstream schools. This phase, which he calls integration, is primarily connected to the issue of the placement of SEN students in mainstream schools and the question of the organisation of education (cf. also Lesar, 2009; Florian, 2014). The assumption is that the appropriate placement of a student in a mainstream school or a special school (appropriate, that is, in terms of the student's diagnosed deficits) will itself have positive effects. This assumption has proved itself over time to be incorrect, since integration cannot in itself eliminate the segregation, marginalisation and discrimination of students.

As a first response to criticisms of integration, a concept of inclusion which Haug (2017) today calls "narrow" appeared in the USA in the 1970s, before subsequently arriving in Europe. Characteristic of this second phase in the development of the concept is that it devotes more attention to the actual pedagogical process. Students should become full members of the class and the school, in which they should be educated alongside their peers from their local area, while at the same time they should have access to differentiated and individualised support, adapted programmes and adapted assessment, in accordance with their abilities and interests. Procedures for identifying a student's deficits are the basis for the selection of interventions by the relevant experts (special pedagogues), who have the special expert knowledge and technical support necessary to eliminate these deficits or at least reduce them. This gives rise to a need for more personnel with special education qualifications in educational institutions, who also bear a greater share of the responsibility for the success and inclusion of SEN students.

The third phase, i.e. the broad understanding of inclusion, is based on fundamentally different premises, in that it proceeds from the belief that a school has to accept diversity as a positive starting point for its activity. The concept is thus no longer tied merely to SEN students, but applies simultaneously to all students facing disabilities in learning and participation (Lesar, 2009) and to students in general, since it is the responsibility of the school to establish learning conditions for all children, and at the same time to teach them to live with difference. As a result of this paradigmatic change, establishing broad understanding is a major challenge that requires the coherent functioning of the entire system (from legislation, programmes and learning materials to school organisation and the level of instruction and relationships), and a change in mentality and existing pedagogical practices. The key shift from a narrow understanding of inclusion to a broad understanding is, in the educational field, the shift from the special pedagogical to the general pedagogical: it is not special pedagogical interventions carried out by special pedagogues that are in the foreground, but the idea of high-quality teaching that is planned and implemented by a teacher: "It is not diagnosis and separate treatment that are important for success at school, but rather the existence of the right conditions for learning - of 
an understanding of what learning is and what it can be in school," points out Thomas (2013, p. 477). Teachers are expected to act in accordance with the principle of individualisation and partial forms of differentiation and thus to select general teaching methods and didactic strategies and adapt them to the abilities of their students. The teacher must, above all, accept diversity as a positive value, be sensitive and responsive to differences between children, and be a practised and proficient didactician. There is, thus, no dichotomy between "normal" and "different" students, but instead a continuum in which the teacher applies common strategies to the specific class they are teaching and takes responsibility for the inclusion and success of all the children in it (Haug 2017). Students, whether or not they are facing disabilities, are active participants in the learning process; even students with learning difficulties become co-creators in the process of resolving learning difficulties (Kodele, 2017).

Not only that, but - as underlined by Arduin (2015) and Thomas (2013), among others the broad understanding of inclusion has significant implications not just at the school level but at the community level as well. Thomas points out that "inclusive education is meaningful only when embedded in understandings about community and communality, only when seen as both reflective of, and creative of, inclusion in society" (2013, p. 485). Diversity should be the foundation of the functioning of the entire community, where everyone has opportunities for inclusion (Ryndak, Jackson \& Billingsley, 2010). Broadly understood inclusion "is based upon a humanistic ethos that values human diversity, emphasises social justice and equity in society" (Arduin 2015, p. 115) and gives priority to communitarianism as opposed to individualism. The liberal discourse from which (moral) individualism derives in fact gives priority to protecting the rights of the individual in relation to institutions. According to liberalism, it is the duty of institutions to ensure suitable conditions for people's inclusion in society and education, but since it overlooks social rights and the spirit of the common good, it overlooks the importance of a commitment to establishing an inclusive society based on solidarity (Kymlicka, 2002). Since the individualist approach is focused on guaranteeing the rights of the individual, in the present-day education system (deriving from Rawls's theory of distributive justice), which emphasises the importance of guaranteeing special rights to everyone who starts off in a disadvantaged position (Kodelja 2006), the importance is underlined of additional engagement and financial investments by which the disadvantaged are supposed to gain. Yet the implementation of specific measures for specific disadvantaged groups is based on an assumption of the deficitary nature of these individuals or groups, who therefore enjoy special assistance (Thomas, 2013). The broad understanding of inclusion is different in its very essence, since it places in the foreground the values of the common good, equality, coexistence and cooperation, and is inseparably connected to a different view of the child or the student. The student is no longer understood through the prism of a deviation from the "normal", but as a person capable of learning (Kroflič, 2013, Reindal, 2016), or as a rich person (Malaguzzi, in Kodele, 2017) who brings a new quality to the life of the community. This diversity in quality is clearly illustrated in the case of deaf people by Salomon: "In most cases people think that deafness is the absence of hearing. But many deaf people experience deafness not as an absence but as a presence" (Salomon, 2012, p. 62). Rather than with an absence, we are dealing with a diversity of qualities, a diversity of identities and their recognition (Thomas, 2013). It can be said that the constructive integration of different concepts of justice has been formulated by Lynch and Lodge (2002) with their 3Rs concept: redistribution, recognition and representation. They supplement redistribution, which derives from Rawls's theory of justice (Rawls, 1971), with recognition. Besides the political equalisation of differences as required by Rawls's difference principle, this introduces a demand for the ethical and epistemological acceptance of the horizon of the other, which through its difference also has the effect of changing the identity of the individual (Fraser \& Honneth, 2003). Representation relates to ways of representing the disadvantaged in issues that are important for them. 
Katja JEZNIK, Klara SKUBIC ERMENC, Jasna MAŽGON. A festival as a pedagogical tool to promote inclusion in the community and in schools

OF EDUCATION

IN THE $21^{\text {st }}$ CENTURY

Vol. 76, No. 2, 2018

162

\section{Global Obstacles en Route to the Establishment of Broadly Inclusive Practices}

In recent decades the education policies of the majority of European countries have attempted to establish education systems that are as inclusive and fair as possible, with a focus on students who frequently drop out of mainstream education because of deviations from the typical development of their peers. The percentage of students educated in segregated institutions is therefore falling at the EU level, but not at the same rate in all countries (European Agency for Special Needs and Inclusive Education, 2014). Parallel to this, the number of categories of special needs is increasing, which has the effect of increasing the percentage of learners defined as SEN students. A contradiction can be noticed: on the one hand a strong movement towards inclusion is present in Europe, while on the other an increasing number of children are identified as SEN students. There are at least two reasons for this: one of them is without a doubt the still-prevailing discourse of professionalism (Lesar, 2009), where the already mentioned medical and special pedagogical treatment of SEN students is in the foreground. Besides this, as Arduin (2015) also points out, a significant connection exists between the narrow understanding of inclusion and the introduction of neoliberal ideas into the sphere of education. As it was shown above, the establishment of the broad concept is tied to the fundamental values and ethical discourses that prevail in a given society, but which, regardless of these differences, are increasingly being undermined by neoliberal economic policy and the so-called global education reform movement (Sahlberg, 2011), which places at the centre of educational reform "market-oriented education policies - especially test-based accountability - [which] affect other regulations and norms, influence teacher policies and set external expectations to how teachers should teach and what students should learn in school" (Sahlberg, 2010, p. 50). The introduction of market mechanisms such as consumer choice, deregulation, privatisation and competition into education contributes to "human beings [being identified] primarily as clients and consumers of a business and regards educational institutions as commodity exchanges and commercial bodies, instead of means of social equalisation and national integration. [...] In this context, competitive success, as opposed to absolute achievement, takes precedence in practice" (Arduin, 2015, p.108).

\section{The Slovenian Approach to Realising a More Inclusive Education System}

Although neoliberal market-oriented policies have not (yet) prevailed in Slovenia, a liberalistic discourse nevertheless dominates, as demonstrated by, among other things, concern for maintaining the same standards of knowledge (especially in compulsory education) (White Paper, 1995). This represents a unique barrier to the adoption of the broad idea of inclusion. Efforts for more inclusively oriented education began at the start of the new millennium with the adoption of the Placement of Children with Special Needs Act, 2012 (hereinafter: the Act), which threw open the door of mainstream education to various groups of SEN students. After numerous updatings and a broadening of the definition of SEN, the Act today defines the following groups as students with SEN: children with intellectual disabilities, blind and visually impaired children, deaf and hearing impaired children, children with speech and language disorders, physically handicapped children, chronically ill children, children with deficits in specific areas of learning, children with autistic disorders and children with emotional and behavioural disorders who require the adapted provision of education programmes with additional specialised assistance or adapted education programmes/special education programmes (Article 2) (Placement of Children with Special Needs Act, 2012). The Act (2012) provides that the decision on the manner of integration of students with SEN in the education system is taken by an expert panel, which during the placement process defines the special needs of the students in question and places them in one of several education programmes for SEN 
students in accordance with their needs or approves additional specialised assistance within mainstream curriculum. The Act distinguishes between several types of education programme, including two programmes with adapted provision and additional specialised assistance aimed at students who are able to achieve the goals of the mainstream elementary curriculum, and two programmes with lower performance criteria aimed at students with intellectual disabilities. An individual school can offer multiple programmes simultaneously, but in the case of lower performance criteria they are in most cases provided in specialised educational institutions (very rarely in separate classes within mainstream schools). At the end of the 2013/14 academic year and the start of the 2014/15 academic year, $8.4 \%$ of all students were SEN students. A quarter of them were enrolled in separate specialised educational institutions, while the other three quarters were enrolled in mainstream primary schools (Osnovnošolsko izobraževanje ..., 2015).

The Act may be said to reflect the narrow understanding of inclusion because it prescribes procedures that derive from diagnosis of a child's deficits, which are the basis for the inclusion of a student in the appropriate programme and includes a determination of the interventions to be carried out by the appropriate special pedagogical personnel. Moreover, as it was already shown (Jeznik, Mažgon \& Ermenc, 2017; Šelih, 2015), while the Act does allow the enrolment of children with mild intellectual disability in mainstream schools, and thus also the integration of standard and adapted programmes, this practice has not taken off because the basic conditions for the coordination of two or more programmes within a single class have not been met.

Two contradictory paradigms still exist among experts - something that can also be understood as a consequence of long years of teacher education policy. The system of study followed by future pedagogical workers is a two-track system that separates the study of special and rehabilitation pedagogy from general pedagogical programmes. This means that some teachers receive training that provides them with the competences for work with SEN students, while others are prepared for work in mainly homogeneous classes with students who correspond to the expected development for their age and, with individualisation and partial differentiation, are capable of achieving the minimum standards of knowledge. This model of teacher education and the idea that SEN students deserve positive discrimination in the form of the additional expert help offered by special pedagogues have the effect of reducing teachers' sense of responsibility for dealing with learning difficulties (Lesar 2017).

\section{Problem of Research}

Against this theoretical backdrop, the general aim of the research was designed. Its main goal was therefore to examine the attitudes about persons with special needs of participants at the Play With Me festival, and to gain deeper insight into their understanding of inclusion. Hence, the following research questions were formulated:

1. What are the attitudes of festival participants about persons with special needs and inclusion?

2. Are there any differences in the scores given to the statements depending on the role played by participants at the festival, the type of institution they come from and whether or not they have experience of SEN students in the context of their job or their studies?

3. How do participants understand the concept of inclusion from the point of view of the narrow and broad understandings of the concept?

\section{Research Focus}

The discussion on the importance and role of the narrow and broad understandings of inclusion serves as the theoretical basis of the research, which analysed the responses of par- 
Katja JEZNIK, Klara SKUBIC ERMENC, Jasna MAŽGON. A festival as a pedagogical tool to promote inclusion in the community and in schools

\begin{abstract}
PROBLEMS
OF EDUCATION

IN THE $21^{\text {st }}$ CENTURY

Vol. 76, No. 2, 2018

164 ticipants in the Play With Me festival. The research focus was on the question of how inclusion and inclusive culture were understood by those who participated in the main spring event in different roles (as volunteers or as mentors), with regard to the institution they come from (special or mainstream educational institution, association or NGO), and with regard to whether they have experience with SEN individuals in their work or studies. Participants' attitudes on inclusion were measured and their understanding of the concept of inclusive culture analysed. The central assumption was that the self-assessment and descriptions obtained from the participants largely reflect a broad understanding of inclusion. This assumption is based on the findings of a study already conducted among a similar population in the context of the festival (Jeznik, Mažgon \& Ermenc, 2017). Because of the specific circumstances surrounding the (non-)realisation of the broad idea of inclusion in Slovenia's educational institutions, the festival draws particular research attention. Its organisers have designed the festival as a specific activity in order to promote inclusive practices at the level of the institutions, individuals (professionals and volunteers) and, even more, at the level of the wider community. The festival connects the focus of the events with extracurricular activities, where play takes centre stage. Additionally, the festival events take place in the city centres, which increases awareness of the importance of inclusivity as a positive value of the community.
\end{abstract}

\title{
Methodology of Research
}

\section{General Background}

The festival organisers want to create opportunities for the inclusion of individuals with or without special needs in a variety of connecting activities, both in and outside school, including those attending special educational institutions. At the same time, it is their intention to increase the active presence of individuals with special needs in the public spaces of life. They understand inclusion as interaction between different participants that is based on the participants' desire to observe and interact, and on their interest in relationships and partnerships with others (Kotnik, 2011), and hold the view that individuals with special needs are only able to exercise their rights adequately in a school or community that spontaneously accepts difference as a new quality of existence (Kroflič, 2003). At the practical level this is reflected through yearround festival activities (Be an Artist, Be a Traveller, Be an Athlete), while the main festival event takes place in city centres in the spring. Through a wide range of activities, the festival organisers promote the social integration of children, adolescents and adults with SEN and people with typical development of all generations. Numerous preschools, schools, institutions, associations, NGOs and individuals, including people who happen upon an individual event by chance, take part in the activities each year.

\section{Sample}

The questionnaire was completed by 139 respondents, non-randomly selected from the population of 215 mentors and 125 volunteers taking part at the festival. More than half (just under $52 \%$ ) of whom were mentors of students taking part in the festival, while just over $42 \%$ were volunteers running various festival activities. Eight respondents selected the answer "other". The majority of participants (just over 63\%) had already taken part in the festival at least once, while just over a third (just under 37\%) were attending for the first time. The largest group of respondents (a total of 34.6\%) had been in employment for between 11 and 30 years, just under $31 \%$ had been in employment for 31 years or more, and just over a fifth had been in employment for less than 10 years. The largest group of respondents came from elementary schools offering programmes with adapted provision and additional specialised assistance 
aimed at students who are able to achieve the goals of the mainstream primary curriculum, and from schools offering programmes with lower performance criteria aimed at students with intellectual disabilities $(22.3 \%)$. The festival was also attended by individuals from technical and vocational secondary schools (just under 15\%), university faculties (just under 13\%) and associations/NGOs (just over 12\%).

\section{Instruments and Procedures}

In May 2017 the main spring event of the Play With Me festival took place in four locations around Slovenia. An online questionnaire was created for the purpose of collecting data and was emailed to the participating mentors and volunteers in June 2017. Recipients of the email were given access via a link to an anonymous questionnaire which they completed and submitted online. The questionnaire contained a set of demographic questions (role at the festival (mentor, volunteer); participation at the festival (first time, second or subsequent time); festival location; number of years employed in education; institution of origin). The questionnaire contained a Likert scale and open questions. For the purposes of this research a Likert scale was created on the basis of theoretical concepts of narrow and broad understanding of inclusion, in order to measure the general attitudes of participants on persons with special needs and inclusion (4 statements) and their attitudes on the place where inclusion should be provided (4 statements). Respondents used a four-point scale to express their level of agreement or disagreement with individual statements. Statistical analysis showed that the scale was reliable (Cronbach's coefficient $\alpha \geq 0.70$ ), and valid (the first factor explained $20 \%$ of the variance). The results were supplemented by participants' answers to an open question about what they understand by the term "inclusive culture". The other questions are not the focus of this article and are not presented here.

\section{Data Analysis}

Once the survey was complete, the data were exported into SPSS statistical processing software. The data is presented in frequency and structural tables and checked the hypotheses using Likelihood ratio Chi-Square test since the expected counts were too low (more than 20\%) to meet the criteria for using the Pearson Chi-square test.

The answers to the two open questions were processed in accordance with qualitative analysis. The process of analysing qualitative data predominantly involved coding the data and making sense of amounts of data from open-ended questions by reducing the volume of raw information. In the second step significant patterns were identified, the meaning drawn from the data and subsequently a logical chain of evidence built (Patton, 2002). On the basis of the theoretical concepts of narrow and broad definition of inclusion, the categories were compiled, and participants' answers placed within them. In this case this was a deductive approach (Flick, 2015). 
Katja JEZNIK, Klara SKUBIC ERMENC, Jasna MAŽGON. A festival as a pedagogical tool to promote inclusion in the community and in schools

\author{
PROBLEMS \\ OF EDUCATION \\ IN THE $21^{\text {st }}$ CENTURY \\ Vol. 76, No. 2, 2018 \\ Results of Research
}

General Attitudes on Inclusion and Persons with Special Needs

General attitudes on inclusion and persons with special needs were measured (Table 1).

Table 1. General attitudes on inclusion and persons with special needs.

\begin{tabular}{|c|c|c|c|c|c|c|}
\hline General attitudes & & $\begin{array}{l}\text { Strongly } \\
\text { disagree }\end{array}$ & Disagree & Agree & $\begin{array}{l}\text { Strongly } \\
\text { agree }\end{array}$ & Total \\
\hline $\begin{array}{l}\text { A focus on inclusion requires a lot of effort } \\
\text { from the individual. }\end{array}$ & $\begin{array}{l}f \\
\%\end{array}$ & $\begin{array}{l}2 \\
1.5\end{array}$ & $\begin{array}{l}17 \\
13.0\end{array}$ & $\begin{array}{l}69 \\
52.7\end{array}$ & $\begin{array}{l}43 \\
32.8\end{array}$ & $\begin{array}{l}131 \\
100.0\end{array}$ \\
\hline $\begin{array}{l}\text { A focus on inclusion requires a lot of effort } \\
\text { from the group. }\end{array}$ & $\begin{array}{l}f \\
\%\end{array}$ & $\begin{array}{l}2 \\
1.5\end{array}$ & $\begin{array}{l}22 \\
16.8\end{array}$ & $\begin{array}{l}65 \\
49.6\end{array}$ & $\begin{array}{l}42 \\
32.1\end{array}$ & $\begin{array}{l}131 \\
100.0\end{array}$ \\
\hline $\begin{array}{l}\text { Inclusion is a spontaneous process of accept- } \\
\text { ing difference in society. }\end{array}$ & $\begin{array}{l}f \\
\%\end{array}$ & $\begin{array}{l}4 \\
3.1\end{array}$ & $\begin{array}{l}47 \\
36.4\end{array}$ & $\begin{array}{l}52 \\
40.3\end{array}$ & $\begin{array}{l}26 \\
20.2\end{array}$ & $\begin{array}{l}129 \\
100.0\end{array}$ \\
\hline $\begin{array}{l}\text { I possess enough of the knowledge and skills } \\
\text { I need to foster an inclusive community. }\end{array}$ & $\begin{array}{l}f \\
\%\end{array}$ & $\begin{array}{l}1 \\
0.8\end{array}$ & $\begin{array}{l}46 \\
35.1\end{array}$ & $\begin{array}{l}73 \\
55.7\end{array}$ & $\begin{array}{l}11 \\
8.4\end{array}$ & $\begin{array}{l}131 \\
100.0\end{array}$ \\
\hline
\end{tabular}

Table 1 indicates that the majority of respondents agree or agree strongly with statements A focus on inclusion requires a lot of effort from the individual (85.5\%) and A focus on inclusion requires a lot of effort from the group (just under $82 \%$ ). Statistically significant differences in the score $\left(\chi^{2}=13.542, \mathrm{df}=6 ; \mathrm{p}=.035\right)$ only appeared in the case of the first statement. More than a quarter of those working at associations or NGOs disagree strongly or disagree with this statement, while a majority of those employed at mainstream educational institutions $(92 \%)$ and special educational institutions (just under $90 \%$ ) agree strongly or agree with this statement.

A majority of respondents agree with the statement Inclusion is a spontaneous process of accepting difference in society (60.5\% agree or agree strongly). Those who agree include three quarters of volunteers but just over half of mentors. The differences between the groups are statistically significant $\left(\chi^{2}=16.369, \mathrm{df}=6 ; \mathrm{p}=.012\right)$. In terms of the institution where respondents work, almost 3 quarters of respondents employed at special educational institutions disagree strongly or disagree with this statement. This contrasts with those who are active in associations and NGOs, where more than two thirds agree strongly or agree with this statement $\left(\chi^{2}=14.820, \mathrm{df}=6 ; \mathrm{p}=.022\right)$.

As expected, more than three quarters of those employed at special educational institutions responded that they feel adequately trained or possess enough of the knowledge and skills they need to foster an inclusive community. This figure was lower among those employed in mainstream educational institutions (just over 60\%).

The second set of statements (Table 2) relates to the place where inclusion is provided. 
Katja JEZNIK, Klara SKUBIC ERMENC, Jasna MAŽGON. A festival as a pedagogical tool to promote inclusion in the community and in schools

Table 2. Place where inclusion is provided.

\begin{tabular}{|c|c|c|c|c|c|c|}
\hline Statement & & $\begin{array}{l}\text { Strongly } \\
\text { disagree }\end{array}$ & Disagree & Agree & $\begin{array}{l}\text { Strongly } \\
\text { agree }\end{array}$ & Total \\
\hline $\begin{array}{l}\text { Special educational institutions [...] also } \\
\text { make an important contribution to an inclu- } \\
\text { sive community. }\end{array}$ & $\begin{array}{l}f \\
\%\end{array}$ & $\begin{array}{l}1 \\
0,8\end{array}$ & $\begin{array}{l}8 \\
6,1\end{array}$ & $\begin{array}{l}76 \\
57,6\end{array}$ & $\begin{array}{l}47 \\
35,6\end{array}$ & $\begin{array}{l}132 \\
100,0\end{array}$ \\
\hline $\begin{array}{l}\text { I believe that people from mainstream } \\
\text { preschools/schools/society would accept a } \\
\text { person with special needs into their group. }\end{array}$ & $\begin{array}{l}f \\
\%\end{array}$ & $\begin{array}{l}1 \\
0,7\end{array}$ & $\begin{array}{l}15 \\
10,9\end{array}$ & $\begin{array}{l}89 \\
65,0\end{array}$ & $\begin{array}{l}32 \\
23,4\end{array}$ & $\begin{array}{l}137 \\
100,0\end{array}$ \\
\hline $\begin{array}{l}\text { Inclusion is connected to the location of } \\
\text { education of the individual. }\end{array}$ & $\begin{array}{l}f \\
\%\end{array}$ & $\begin{array}{l}7 \\
5,3\end{array}$ & $\begin{array}{l}39 \\
29,8\end{array}$ & $\begin{array}{l}74 \\
56,5\end{array}$ & $\begin{array}{l}11 \\
8,4\end{array}$ & $\begin{array}{l}131 \\
100,0\end{array}$ \\
\hline $\begin{array}{l}\text { Inclusive education means educating all } \\
\text { students in one class. }\end{array}$ & $\begin{array}{l}f \\
\%\end{array}$ & $\begin{array}{l}9 \\
6,9\end{array}$ & $\begin{array}{l}49 \\
37,7\end{array}$ & $\begin{array}{l}58 \\
44,6\end{array}$ & $\begin{array}{l}14 \\
10,8\end{array}$ & $\begin{array}{l}130 \\
100,0\end{array}$ \\
\hline
\end{tabular}

Of all the above statements, respondents agreed most (93.2\%) with the statement Special educational institutions (e.g. elementary schools with lower performance criteria, special education units, sheltered work centres) also make an important contribution to an inclusive community.

Respondents also expressed a high degree of agreement with the statement $I$ believe that people from mainstream preschools/schools/society would accept a person with special needs (over $88 \%$ ). Analysis of the differences between sub-groups showed that the statement was equally supported by all respondents working at associations or NGOs, and to a lesser extent by the employees of special educational institutions (a fifth of whom do not agree with this statement) and those employed in mainstream educational institutions (eleven or just under $14 \%$ of whom do not agree with this statement). The differences are statistically significant at the level $\mathrm{p}=.008\left(\chi^{2}=17.362, \mathrm{df}=6\right)$.

A large percentage of respondents agree that inclusion is connected to the location of education of the individual (64.9\% agree or agree strongly). There is more agreement that inclusion is connected to the location of education (i.e. placement) of the individual among those who do not encounter persons with special needs in the context of their work or studies. This view is held by over $78 \%$ of respondents who do not work with persons with SEN. Among those who do work with persons with SEN, this percentage is smaller - just under $60 \%$. While differences at the level of the sample are essential, they are not statistically significant.

Respondents expressed a more equal degree of agreement and disagreement with the statement Inclusive education means educating all students in one class, and a comparison of responses by sub-groups did not show statistically significant differences for either of the two statements.

\section{Understanding of the Term "Inclusive culture"}

The results were supplemented by findings deriving from analysis of answers to the open question: Please state what you understand by the term "inclusive culture". 
Katja JEZNIK, Klara SKUBIC ERMENC, Jasna MAŽGON. A festival as a pedagogical tool to promote inclusion in the community and in schools

PROBLEMS

OF EDUCATION

IN THE $21^{\text {st }}$ CENTURY Vol. 76, No. 2, 2018

Table 3. Understanding of the term "inclusive culture".

\begin{tabular}{|c|c|c|c|}
\hline Category & $\begin{array}{l}\text { Sub-cate- } \\
\text { gory }\end{array}$ & Number & Example of statement \\
\hline \multicolumn{4}{|l|}{ Integration } \\
\hline \multicolumn{2}{|c|}{ Educational placement } & 6 & Inclusion of children with special needs in the community of normal children. \\
\hline \multicolumn{2}{|c|}{$\begin{array}{l}\text { An appropriate focus on the } \\
\text { programme is sufficient }\end{array}$} & 1 & \\
\hline \multicolumn{4}{|c|}{ Narrow understanding of inclusion } \\
\hline \multicolumn{2}{|c|}{$\begin{array}{l}\text { Focus on the special needs/ } \\
\text { deficits of the individual or } \\
\text { group }\end{array}$} & 20 & $\begin{array}{l}\text { Inclusion of people with special needs and/or deficits in a particular area in } \\
\text { life and work. }\end{array}$ \\
\hline \multicolumn{2}{|c|}{$\begin{array}{l}\text { Special didactic interven- } \\
\text { tions (e.g. additional expert } \\
\text { help) }\end{array}$} & 1 & $\begin{array}{l}\text { Students with special needs and students with specific learning difficulties } \\
\text { must have adapted methods and forms of work in the educational process, } \\
\text { along with other adaptations and additional expert help, in order to be able } \\
\text { to develop their potentials and master the curriculum. }\end{array}$ \\
\hline \multicolumn{2}{|c|}{$\begin{array}{l}\text { Focus on the right of the in- } \\
\text { dividual to special treatment }\end{array}$} & 1 & Equality among people. \\
\hline \multicolumn{2}{|c|}{$\begin{array}{l}\text { The appearance of a vulner- } \\
\text { able individual }\end{array}$} & l & \\
\hline \multicolumn{4}{|c|}{ Broad understanding of inclusion } \\
\hline \multicolumn{2}{|c|}{ Focus on all individuals } & 20 & $\begin{array}{l}\text { We accept people irrespective of their sexual orientation, culture, religion or } \\
\text { difference in general. }\end{array}$ \\
\hline \multicolumn{2}{|c|}{$\begin{array}{l}\text { Diversity as a positive value } \\
\text { of the community }\end{array}$} & 18 & $\begin{array}{l}\text { A culture in which we are all aware that we are all equal in our difference } \\
\text { (J.Felc). A culture in which people of different abilities work side by side. }\end{array}$ \\
\hline \multicolumn{2}{|c|}{ Positive recognition } & 14 & $\begin{array}{l}\text { That persons with special needs or any marginal groups are properly includ- } \\
\text { ed in society, without prejudices and with concrete possibilities for inclusion. }\end{array}$ \\
\hline \multicolumn{2}{|c|}{ Participation } & 13 & $\begin{array}{l}\text { Participation in joint project by people from all age groups, irrespective of } \\
\text { where they are being educated and where they come from. }\end{array}$ \\
\hline \multicolumn{2}{|c|}{$\begin{array}{l}\text { Elimination of barriers in the } \\
\text { environment }\end{array}$} & 9 & $\begin{array}{l}\text { A culture that recognises individuals and their special needs and is willing to } \\
\text { adapt to them and reduce barriers. It accepts them on an equal basis and } \\
\text { offers them opportunities for inclusion, success and acceptance. }\end{array}$ \\
\hline \multicolumn{2}{|c|}{$\begin{array}{l}\text { General pedagogical ap- } \\
\text { proach (individualisation, } \\
\text { partial differentiation) }\end{array}$} & 4 & $\begin{array}{l}\text { It is also important to raise society's awareness of the importance of inclu- } \\
\text { sion and develop a positive self-image in all students and a good atmos- } \\
\text { phere in the classroom. }\end{array}$ \\
\hline \multicolumn{2}{|c|}{ Appearance of a rich person } & I & \\
\hline \multicolumn{2}{|c|}{$\begin{array}{l}\text { Misunderstanding of the } \\
\text { term }\end{array}$} & 6 & That SEN students with special needs can also be culturally active. \\
\hline \multicolumn{2}{|c|}{ Don't know } & 6 & Don't know \\
\hline \multicolumn{2}{|l|}{ Other } & 8 & Everything we do at the Play With Me festival. \\
\hline
\end{tabular}

A total of 125 respondents answered the question. Six answers indicating misunderstanding of the question were excluded from the analysis. Six respondents answered Don't know. Eight answers were placed in the "Other" group. Some answers were placed in multiple categories, with the result that the total amount of statements is greater than the number of respondents. The key assessment criterion for the remaining answers was the question of whether an individual statement could be placed in one of the predefined categories. The majority of 
statements made by respondents in their open answers related to the broad understanding of inclusion $(\mathrm{N}=78)$ and highlighted a focus on all individuals, difference as a positive value of community, positive recognition, participation, elimination of barriers in the environment and general pedagogical approaches. The number of statements understanding inclusion in the narrow sense was smaller $(\mathrm{N}=22)$ and reflected a focus on special needs and the deficits of an individual or group. Six statements reflect integration, with attention focused on the question of where the education of persons with special needs should take place.

\section{Discussion}

A strong degree of conformism is present in answers relating to social norms and social values (Ellingson, Smith \& Sackett, 2001), which also makes it harder to measure of attitudes on inclusion. This research looked at general attitudes on inclusion (Table 1) and specific attitudes tied to the place where inclusion is put into effect (Table 2). This was supplemented by the data obtained with the answers to the open question on what respondents understand by the term "inclusive culture". Given that participation of the festival is voluntary, the participants were expected to have a positive attitude towards inclusion in persons with special needs. Despite the fact that it is hard to measure such an attitude, it was assumed that, because of the nature of the festival events, their position would be closer to the broad understanding of the concept of inclusion than to the narrow one. At the same time, it was researched if the scores they gave to the various statements reflected the role they had at the festival and the institutions they came from. And finally, the research aimed to find out if the participants' attitudes differed according to whether or not they had experience of persons with special needs in their work or studies. Similar research shows that teachers from mainstream schools in Slovenia are frequently reserved in their attitude towards persons with intellectual disabilities and are not in favour of their inclusion in mainstream classes (Schmidt \& Čagran, 2011; Rovšek, 2013; Štefanič, 2016). On the other hand, research also shows that teachers from special educational institutions tend to be in favour of non-integrated forms of education for persons with special needs (Kavkler \& Adlešič, 2010). Few studies have been carried out on attitudes towards inclusion outside the educational context. In the case of the Play With Me festival Kotnik (2017) in a qualitative study based on 30 interviews found out that attitudes towards persons with special needs and inclusion differed depending on whether or not the interviewees had personal experience of persons with special needs. She also found that attitudes towards inclusively oriented activities as facilitated by the festival were positive.

The results of this research confirmed the expectations: participants generally expressed a favourable attitude towards the idea of inclusion. They showed the highest degree of agreement with the statement Special educational institutions (e.g. elementary schools with lower performance criteria, special education departments, sheltered work centres) also make an important contribution to an inclusive community, as already shown by a previous piece of research (Jeznik, Mažgon \& Ermenc, 2017). They also supported the statement I believe that people from mainstream preschools/schools/society would accept a person with special needs (over 88\%). Those from associations and NGOs were most in favour. Regarding the statements Inclusion is connected to the location of education of the individual (56.5\% agree with the statement) and Inclusive education means educating all students in one class (55.4\% agree or strongly agree with that statement), no differences were observed between the sub-groups. The participants most frequently expressed attitudes that reflect elements of the broad understanding of inclusion. At the same time, however, they see special educational institutions as one of the promoters of inclusion and link inclusion to the question of the location of education, which points to an opinion that is relatively consolidated in the educational environment in Slovenia, namely that full integration of SEN students cannot be a successful way of putting a broadly 
Katja JEZNIK, Klara SKUBIC ERMENC, Jasna MAŽGON. A festival as a pedagogical tool to promote inclusion in the community and in schools

PROBLEMS

OF EDUCATION

IN THE $21^{\text {st }}$ CENTURY Vol. 76, No. 2, 2018

170

inclusive culture into practice. This finding can be understood in two ways: either as awareness of the extreme complexity of realising full integration (Haug, 2017), or as understanding of inclusion through the prism of the question of how to include persons with special needs in heterogeneous groups and provide optimal conditions for high-quality learning (Warnock, 2010).

Interestingly, the scores given to the statements indicate that teachers from special educational institutions are the respondents who are least positively inclined towards general statements about inclusion and about SEN students. In the case of two of the four general statements (Table 1), statistically significant differences were apparent among respondents with regard to the institution they come from: the great majority of those employed in mainstream educational institutions (92\%) and those employed in special educational institutions (just under 90\%) agree or strongly agree with the statement $A$ focus on inclusion requires a lot of effort from the individual. The statement is supported to a lower degree $(82 \%)$ by those from associations or NGOs. At the same time almost three quarters of respondents employed at special educational institutions expressed their disagreement with the claim Inclusion is a spontaneous process of accepting difference in society, while more than two thirds of volunteers from associations and NGOs also agreed with it. It is no surprise that pedagogical workers think about inclusion as a question of finding the appropriate place to educate persons with special needs, since their attitude towards SEN students and inclusion is established in the context of the prevailing (narrow) conception of inclusion in education in the country, while these questions are not of key importance for volunteers and they are not burdened by them. Both groups of pedagogical workers incline more towards the view that inclusion is not (nor can be) a spontaneous process of accepting difference. For them, the question of the inclusion of a student is a complex project that requires the establishment of special conditions and specially trained teachers. In the same way, it is no surprise to find that more than three quarters of teachers from special educational institutions feel themselves qualified to foster an inclusive community, since they are the ones who have this special knowledge. On the other hand, it is somewhat surprising to find that as many as $60 \%$ of teachers from mainstream educational institutions feel qualified for this task. This is surprising because of the existing two-track system of teacher education, in which there is a lack of knowledge about the general aspects and, for teachers from mainstream institutions, also the special aspects of inclusion or work with individual groups of frequently excluded children (Messner, Worek \& Peček, 2016; Peček Čuk \& Macura-Milovanović, 2015). The relatively high percentage of agreement can be linked with the statement on assessing one's own abilities to the voluntary nature of the festival, which is an encouraging finding that points to the human resource potential of mainstream schools. The answers of representatives of associations and NGOs were split between the option "Agree" (56\%) and "Disagree" (43\%). Although there are no statistically significant differences between the answers, the results show that for volunteers the attitude and value aspects are more important when it comes to establishing an inclusive culture, along with the belief that it is not only educational institutions and experts with specialist training who are responsible for establishing inclusion.

An additional insight into what participants understand by the term "inclusive culture" was gained through the analysis of open questions. A small number of statements (6) were placed at the lowest level of development of the concept of inclusion (Haug, 2017), i.e. integration. In the context of the narrow conception of inclusion, four sub-categories were created on the basis of the theoretical starting points presented. Analysis of the answers showed that within this conception an association tied to the integration of individuals or groups with special needs into mainstream environments prevails: majority of statements (20) were placed into the subcategory focus on the special needs/deficits of the individual or group; one statement among special pedagogical interventions (e.g. additional expert help), and one in the sub-category focus on the right of the individual to special treatment. No statements were placed in the fourth sub-category, appearance of a vulnerable person. Given the already highlighted critical as- 
sessment of the currently applicable legislation in the country, which is not broadly inclusively designed, it is no surprise that respondents primarily relate inclusion to the inclusion of persons with special needs in suitable education programmes.

The majority of respondents, however, showed attitudes that reflect elements of the broad understanding of inclusion. Therefore, the great majority of statements (70) was placed in one of seven sub-categories of the broad understanding of inclusion. Four of these stand out in terms of numbers: the largest number (20) were placed in the sub-category focus on all individuals, which undoubtedly reflects the influence of the international trends encouraged by The Salamanca Statement (1994). In second place (18 statements) is the sub-category diversity as a positive value of the community (Arduin, 2015; Haug, 2017; Lesar, 2009; Thomas, 2013). In third place (14 statements) comes the sub-category positive recognition (Fraser \& Honneth, 2003 ) and, in fourth place (13 statements), the sub-category participation (Kodele, 2017). Festival participants showed a deviation from the conception that is characteristic of the Slovenian education system, where this deviation is most evident in the question regarding target groups, since SEN students are not at the centre of attention when we ask about establishing an inclusive climate. A high degree of positive evaluation of diversity is also apparent. Difference is not seen as an obstacle but as a challenge and perhaps even as a new quality.

Attitudes that could be placed in the last three categories are less well represented: Nine statements relate to elimination of barriers in the environment, and four to the importance of a general didactic approach in establishing an inclusive culture. In the context of a festival that does not take place in a school environment, the latter is not even surprising. That participants in general think less about the nature of difference, its background and the identity of people facing barriers in education and life is indicated by two findings: no statement could be placed in the seventh sub-category appearance of a rich person (Kodele, 2017), while at the same time no statement could be placed in the category that mirrors it (appearance of a vulnerable person) in the context of the narrow understanding of inclusion.

\section{Conclusions}

Owing to the limitations of the research, some cautious about the findings are necessary. The research was based on a non-random and relatively small sample, which indicates - but does not prove - trends of connections and, together with qualitative analysis of open questions, allows interpretations that have more the nature of theses for further research than that of generalised findings. The method of collecting data also represents a limitation. This took place in electronic form, a few days after the main spring event of the festival, and the questionnaire was only completed by mentors and volunteers, not students. Moreover, the research's focus on a single group of with special needs, namely persons with intellectual disabilities, is a further limitation. Research carried out in the context of Slovenia indicates that views differ on persons with special needs and their inclusion in mainstream schools.

Having these limitations in mind, the results are nevertheless encouraging. Not only because they are closer to the broad understanding of inclusion, but also because they show that both in education and in civil society there are individuals who (can) function as promoters of inclusion. One of the tasks of education is to contribute to the realisation of the principles of inclusion, including in the wider community, therefore a festival like this can be seen as an innovative pedagogical tool by means of which a special educational institution is attempting to reconcile the tasks of education with the tasks of wider social policies and in this way strengthen the inclusive orientation both of the education system as a whole and of the community at large.

It appears that people who are generally favourable towards ideas of inclusion can be divided into two groups according to the way they understand of inclusion and possibilities for its realisation. On the one hand, there are individuals who see inclusion as a complex professional

\begin{tabular}{l} 
OF EDUCATION \\
IN THE 21 $1^{\text {st }}$ CENTURY \\
Vol. 76, No. 2, 2018 \\
\hline 171
\end{tabular} 
Katja JEZNIK, Klara SKUBIC ERMENC, Jasna MAŽGON. A festival as a pedagogical tool to promote inclusion in the community and in schools

\begin{abstract}
PROBLEMS
OF EDUCATION

IN THE $21^{\text {st }}$ CENTURY Vol. 76, No. 2, 2018

172 issue for which specialised knowledge is necessary and in which considerable effort needs to be invested. On the other hand, there are individuals - more frequently volunteers than pedagogical workers - who see inclusion above all as a matter of a positive attitude towards diversity and the establishment of conditions in which everyone can coexist. The former view coincides with the narrow understanding of inclusion and the latter with the broad understanding of inclusion. This thesis is to a certain extent provocative and tentative. In the context of inclusive practice, further research might give more precise and in-depth explanation on the role and relationship between professionals versus volunteers as well as on the role of specialised knowledge and its relation to attitudes professionals hold.
\end{abstract}

\title{
Acknowledgements
}

This article is a product of a research program No. P5-0174 Pedagogical-andragogical research - Learning and education for quality life in a community, funded by Slovenian Research Agency, and of a bilateral project between University of Belgrade and University of Ljubljana: No. BI-RS/16-17-011 The preparation of pedagogical students for work in inclusive settings.

\section{References}

Arduin, S. (2015). A review of the values that underpin the structure of an education system and its approach to disability and inclusion, Oxford Review of Education, 41 (1), 105-121, DOI: 10.1080/03054985.2015.1006614.

Biesta, G. J. J. (2013). The beautiful risk of education. Boulder: Paradigm Publishers.

Booth, T., \& Ainscow, M. (2002). Index for inclusion: Developing learning and participation in schools. Bristol: Centre for Studies on Inclusive Education.

Ellingson, J. E., Smith, D. B., \& Sackett, P. R. (2001). Investigating the Influence of Social Desirability on Personality Factor Structure. Journal of Applied Psychology, 86 (1), 122-133.

European Agency for Special Needs and Inclusive Education (2014). European Agency Statistics on Inclusive Education: 2014 Dataset Cross-Country Report. (J. Ramberg, A. Lénárt, \& A. Watkins, Eds.). Odense, Denmark. Retrieved 23/2017, from https://www.european-agency.org/publications/ereports/easie-2014-dataset-cross-country-report.

Flick, U. (2015). Introducing research methodology: A beginner's guide to doing a research project. London: Sage.

Florian, L. (2014). What counts as evidence of inclusive education? European Journal of Special Needs Education, 29 (3), 286-294. DOI: 10.1080/08856257.2014.933551.

Fraser, N., \& Honneth, A. (2003). Redistribution or Recognition? A political-philosophical exchange. London; New York: Verso.

Haug, P. (2017). Understanding inclusive education: Ideals and reality. Scandinavian Journal of Disability Research, 19 (3), 206-217. DOI: 10.1080/15017419.2016.1224778.

Jeznik, K., Mažgon, J., Ermenc, K. S. (2017). The contribution of a special educational institution to a more inclusive society. Zbornik Instituta za Pedagoška Istraživanja, 49 (1), 117-138. DOI: https://doi.org/10.2298/ZIPI1701117J.

Kavkler, M., \& Adlešič, I. (2010). Razvoj inkluzivne prakse s pomočjo inkluzivnih timov: zbornik prispevkov [The Development of inclusive practice with the support of inclusive teams: Collection of papers]. Ljubljana: Zavod za šolstvo.

Kodele, T. (2017). Participacija učencev v procesu reševanja njihovih učnih težav [Pupils' participation in the process of solving their learning difficulties]. (Doctoral dissertation). Ljubljana: Univerza $\mathrm{v}$ Ljubljani: Pedagoška Fakulteta.

Kotnik, B. (2011). Med iluzijo in resničnostjo - inkluzija otrok s posebnimi potrebami [Between illusion and reality - the inclusion of students with special needs]. Educa: strokovna revija za področje varstva, vzgoje in izobraževanja predšolskih otrok in otrok na razredni stopnji osnovne šole, 20 $(2 / 3), 60-61$. 
Kotnik, J. (2017). Societal point of view to the children with special needs. Conference proceedings with peer review, 153-163. Retrieved 23/2017, from http://almamater.si/-s292.

Kroflič, R. (2003). Etika in etos inkluzivne šole-vrtca. [Ethics and ethos of inclusive school-preschool] In M. Resman (Ed.), Integracija, inkluzija v vrtcu, osnovni in srednji šoli: teorija in praksa (konferenčni zbornik) [Integration, inclusion in preschool, elementary and secondary school: theory and practice (conference proceedings)] (pp. 24-35). Ljubljana: Zveza društev pedagoških delavcev Slovenije.

Kroflič, R. (2013). Pripoznanje zmožnega otroka in ontološki angažma v dialogu - pogoj participacije in vzgoje za aktivno državljanstvo [Recognition of a capable child and ontological engagement in a dialogue - the precondition of participation and education for active citizenship]. In T. Taštanoska (Ed.), Nacionalna konferenca Socialna in državljanska odgovornost (Zbornik prispevkov) [National conference Social and civil responsibility (Conference proceedings)] (pp. 53-57). Ljubljana: Ministrstvo RS za izobraževanje, znanost, kulturo in šport. Retrieved 15/12/2017, from http:// www.zrss.si/sidro/files/SIDRO2013-zbornik.pdf.

Kymlicka, W. (2002). Contemporary political philosophy. An introduction (2nd ed.). Oxford: Oxford University Press.

Lesar, I. (2009). Šola za vse? Ideja inkluzije v šolskih sistemih [School for everyone? Ideas of inclusion in school systems]. Ljubljana: Pedagoška fakulteta.

Lesar, I. (2017). Mapping inclusive education within the discipline of Pedagogy. Comparative analysis of new study programmes in Slovenia. International Journal of Inclusive Education, DOI: 10.1080/13603116.2017.1402376.

Lynch, K., \& Lodge, A. (2002). Equality and power in schools: redistribution, recognition and representation. London: Routledge.

Messner, E., Worek, D., \& Peček, M. (Eds.) (2016). Teacher education for multilingual and multicultural settings. Graz: Leykam.

Mitchell, D. (2015). Inclusive education is a multi-faceted concept. CEPS Journal: Center for Educational Policy Studies Journal, 5 (1), 9-30.

Osnovnošolsko izobraževanje mladine in odraslih, Slovenija, konec šolskega leta 2013/14 in začetek 2014/15 [Elementary education of the youth and adults, Slovenia, the end of school year 2013/14 and the beginning of 2014/15]. (2015). Retrieved 29/10/2017, from http://www.stat.si/StatWeb/ prikazi-novico id $=5133 \&$ idp $=9$ \&headerbar $=7$.

Patton, M. Q. (2002). Qualitative research \& evaluation methods. 3rd. Thousand Oaks, California: Sage.

Peček, M., \& Macura-Milovanović, S. (2015). Do admission criteria for teacher education institutions matter? A comparative study on beliefs of student teachers from Serbia and Slovenia about inclusive practices. Teachers and teaching: Theory and Practice, 21 (3), 260-276. DOI: 10.1080/13540602.2014.953824.

Placement of Children with Special Needs Act (2012). Uradni list RS, št. 58/11, 40/12 - ZUJF in 90/12.

Rawls, J. (1971). A theory of justice. Cambridge, Massachusetts: The Belknap Press of Harvard University Press.

Reindal S.M. (2016). Discussing inclusive education: an inquiry into different interpretations and a search for ethical aspects of inclusion using the capabilities approach. European Journal of Special Needs Education, 31 (1), 1-12.

Rovšek, M. (2013). Značilnosti usmerjanja otrok in mladostnikov z motnjami v duševnem razvoju [The referral process characteristics and children /adolescents with intellectual disabilities]. (Doctoral dissertation). Univerza v Ljubljani, Pedagoška fakulteta, Ljubljana.

Ryndak, D. L., Lewis Jackson, L., \& Billingsley, F. (2000) Defining school inclusion for students with moderate to severe disabilities: What do experts say? Exceptionality: A Special Education Journal, 8 (2), 101-116, DOI: 10.1207/S15327035EX0802_2.

Sahlber, P. (2010). Rethinking accountability in a knowledge society. Journal of Educational Change, 11, 45-61, DOI 10.1007/s10833-008-9098-2.

Sahlber, P. (2011). Finnish Lessons. New York: Teachers College Press.

Schmidt, M. \& Čagran, B. (2011). Stališča slovenskih učiteljev o vplivu integracije/ in inkluzije na učence z različnimi vrstami posebnih potreb v osnovni šoli [The views of Slovenian teachers on integration/ and inclusion of students with different types of special needs in elementary school]. Šolsko polje: revija za teorijo in raziskave vzgoje in izobraževanja, $22(1 / 2), 55-72$. 
Katja JEZNIK, Klara SKUBIC ERMENC, Jasna MAŽGON. A festival as a pedagogical tool to promote inclusion in the community and in schools

\section{PROBLEMS \\ OF EDUCATION \\ IN THE $21^{\text {st }}$ CENTURY \\ Vol. 76, No. 2, 2018}

Šelih, A. (2013). Pravne obveznosti RS pri vključevanju otrok s posebnimi potrebami, zlasti otrok z motnjo v duševnem razvoju, $v$ redne šole [The legal obligations of the Republic of Slovenia arising from integrating children with special needs, especially children with mental development disorders, into regular schools]. Sodobna pedagogika, 64 (2), 64-74.

Štefanič, S. (2016). Inkluzija otrok z lažjo motnjo v duševnem razvoju v večinske osnovnošolske izobraževalne programme [The inclusion of children with mild intellectual disabilities into the mainstream primary school]. (MSc thesis). Univerza v Ljubljani, Pedagoška fakulteta, Ljubljana.

The Salamanca statement and framework for action on special needs education (1994). Adopted by the World Conference On Special Needs Education: Access And Quality Salamanca, Spain, 7-10 June. Retrieved 10/10/2017, from http://www.unesco.org/education/pdf/SALAMA_E.PDF.

Thomas, G. (2013). A review of thinking and research about inclusive education policy, with suggestions for a new kind of inclusive thinking. British Educational Research Journal, 39 (3), 473-490.

Warnock, M. (2010). Special educational needs: A new look. In M. Warnock \& B. Norwich (Eds.), Special educational needs: A new look (pp. 11-46). New York: Continuum.

White paper on education in the Republic of Slovenia. (1996). Ljubljana, Ministry of Education and Sport.

Received: February 06, 2018

Accepted: April 10, 2018

Klara Skubic Ermenc
Katja Jeznik

$\mathrm{PhD}$, Teaching Assistant, University of Ljubljana, Faculty of Arts, Department of Educational Sciences, Aškerčeva 2, 1000 Ljubljana, Slovenia.

E-mail: katja.jeznik@ff.uni-lj.si

Website: http://www.pedagogika-andragogika.com/teacher/24

$\mathrm{PhD}$, Associate Professor, University of Ljubljana, Faculty of Arts, Department of Educational Sciences, Aškerčeva 2, 1000 Ljubljana, Slovenia. E-mail: klara.skubic-ermenc@ff.iuni-lj.si

Website: http://www.pedagogika-andragogika.com/teacher/16

Jasna Mažgon
$\mathrm{PhD}$, Associate Professor, University of Ljubljana, Faculty of Arts, Department of Educational Sciences, Aškerčeva 2, 1000 Ljubljana, Slovenia. E-mail: jasna.mazgon@ff.uni-lj.si Website: http://www.pedagogika-andragogika.com/teacher/12 